\title{
PENATAAN ADMINISTRASI UMUM DI KAMPUNG YOBOI DISTRIK SENTANI KABUPATEN JAYAPURA
}

\author{
Dorthea Renyaan $^{1}$, Sriyono ${ }^{2}$ \\ ${ }^{1,2)}$ Program Studi Ilmu Administrasi Publik, Fakultas Ilmu Sosial dan Ilmu Politik, Universitas \\ Cenderawasih Jayapura \\ e-mail: renyaan_dorthea@yahoo.com
}

\begin{abstract}
Abstrak
Penataan administrasi pemerintahan desa sebagaimana telah diamanatkan dalam Permendagri Nomor 47 Tahun 2016 tentang Administrasi Pemerintahan Desa belum sepenuhnya dapat diimplementasikan di Kampung Yoboi. Kurangnya pemahaman aparatur kampung menjadi salah satu faktor pemicu akan permasalahan tersebut. Untuk itu, dilaksanakan kegiatan pengabdian kepada masyarakat yang bertajuk "Penataan Administrasi Umum di Kampung Yoboi Distrik Sentani Kabupaten Jayapura".Adapun metode yang digunakan adalah; pertama, penyampaian materi tentang Administrasi Pemerintahan Kampung, khususnya mengenai Buku Administrasi Umum; Kedua, memfasilitasi pembuatan buku administrasi umum secara lengkap. Hasil dari kegiatan pengabdian kepada masyarakat ini berpangkal terhadap peningkatan pemahaman aparatur Kampung Yoboi mengenai tata kelola administrasi umum yang baik dan benar, serta dapat mengisi ke dalam buku administrasi umum, termasuk telah tersedianya Buku Pedoman Administrasi Umum di Kampung Yoboi. Dimana sebelumnya administrasi belum tertata dan teratur kini berubah menjadi lebih baik dengan terciptanya buku-buku administrasi umum yang secara terus menerus dapat diisi oleh aparat kampung dalam menghasilkan data dan informasi desa yang terbaru dan akurat.
\end{abstract}

Kata Kunci: Penataan, Administrasi Umum, Data, Informasi Kampung

\begin{abstract}
The arrangement of village government administration as mandated in Permendagri No. 47 of 2016 on Village Administration has not been fully implemented in Yoboi Village. The lack of understanding of the village apparatus is one of the trigger factors for the problem. Therefore, community service activities were carried out entitled "General Administration Arrangement in Yoboi Village Sentani District Jayapura Regency". The methods used are; submission of material about the Administration of village Government, especially regarding the General Administration Book, 2) facilitates the complete creation of general administration books. The result of this community service activity is based on increasing understanding of Yoboi Village apparatus regarding good and correct general administration governance, and can be filled into the general administration book, including the availability of General Administration Manual in Yoboi Village. Where previously un organized and orderly administration has now changed for the better with the creation of general administration books that can be continuously filled by village officials in producing the latest and accurate village data and information.
\end{abstract}

Keywords: Setup, General Administration, Data, Village Information

\section{PENDAHULUAN}

Desa atau di wilayah Papua dikenal dengan istilah Kampung dalam Undang-undang nomor 6 Tahun 2014, selanjutnya Desa dapat diartikan bahwa desa adat atau yang disebut dengan nama lain selanjutnya disebut Desa adalah kesatuan masyarakat hukum yang memiliki batas wilayah yang berwenang untuk mengatur dan mengurus urusan pemerintahan, kepentingan masyarakat setempat berdasarkan prakarsa masyarakat, hak asal usul, dan/atau hak tradisional yang diakui dan dihormati dalam sistem pemerintahan Negara Kesatuan Republik Indonesia, (Ilham, Muttaqin, \& Idris, 2020). Di Papua perubahan istilah desa menjadi kampung terjadi sejak diimplementasikannya Undang-undang Nomor 21 Tahun 2001 tentang pemberlakuan Otonomi Khusus (Otsus) bagi 
Provinsi Papua, selain perubahan istilah desa menjadi kampung termasuk adanya perubahan dari istilah kecamatan menjadi distrik, Anangkota dalam (Yumame, et al., 2020).

Untuk mengurus dan mengatur sistem pemerintahan ditingkat kampung tentunya dibutuhkan aparatur yang memiliki kualitas Sumber Daya Manusia (SDM) yang memadai, sehingga penyelenggaraan pemerintahan dapat berjalan menuju tata kelola pemerintahan yang baik (Good Governance). Keberadaan aparat kampung yang juga diserahi tugas dibidang administrasi, menduduki posisi yang sagat penting karena sebagai organ pemerintah yang paling bawah mengetahui segala kondisi dan permasalahan yang ada diwilayahnya. Informasi tersebut dikoordinasikan pada pemerintah tingkat kecamatan/distrik karena dibutuhkan dalam pengambilan kebijaksanaan daerah maupun nasional untuk kebutuhan pembangunan secara menyeluruh, (Arsjad, 2018).

Mengacu pada Peraturan Menteri Dalam Negeri (Permendagri) Nomor 81 Tahun 2015 Tentang Evaluasi Perkembangan Desa dan Kelurahan. Salah satu poin penting dalam Permendagri tersebut adalah mengenai terpenuhinya administrasi kampung yang lengkap di Kantor Kampung. Menurut Permendagri Nomor 47 Tahun 2016 Administrasi Pemerintahan Desa/Kampung adalah keseluruhan proses kegiatan pencatatan data dan informasi mengenai Pemerintahan Desa pada Buku Register Desa. Untuk memenuhi administrasi kampung yang lengkap haruslah memiliki buku administrasi umum, buku administrasi penduduk, buku administrasi keuangan, buku administrasi pembangunan, dan buku administrasi lainnya sesuai kebutuhan desa yang bersangkutan sebagaimana telah diamanatkan dalam Peraturan Menteri Dalam Negeri Nomor 47 Tahun 2016 Tentang Administrasi Pemerintahan Desa.

Penyelenggaraan pemerintahan di Kampung Yoboi Distrik Sentani Kabupaten Jayapura berdasarkan hasil pengamatan awal belum cukup efektif dalam menunjang penyelenggaraan Pemerintah Kampung. Dimana adanya indikasi bahwa pengelolaan administrasi belum berjalan sesuai dengan aturan yang berlaku. Hal ini kemudian dapat dilihat dari jenis buku administrasi umum yang digunakan di Kampung Yoboi hanya sebatas pada buku agenda surat masuk dan surat keluar tetapi untuk buku data inventaris desa, buku ekspedisi dan buku data tanah belum tersedia. Sementara untuk tertib administrasi kampung dilakukan oleh aparatur yang telah diberikan tugas dan tanggung jawab untuk melaksanakan tugas tersebut dengan baik, namun hal tersebut bukan pekerjaan yang mudah karena membutuhkan pengalaman dan pengetahuan yang memadai sehingga hasil kerja akan menjadi efektif dan efesien, (Lembong., Lapian., \& Kalangie, 2017). Tata kelola administrasi kampung yang baik dan benar selanjutnya akan menjadi faktor penunjang pembangunan kampung terhadap kemasyalatan serta kesejatraan rakyat. Begitupulah sebaliknya, jika pemerintah tidak dengan bijak mengelola serta menata administrasi kampung, maka akan menjadi patologi tersendiri terhadap kemajuaan suatu desa, Trisno Mais et al. dalam (Prasodjo, 2017).

Berangkat dari urain diatas, maka dinilai penting untuk dilakukan Penataan Administrasi Umum Di Kampung Yoboi Distrik Sentani Kabupaten Jayapura. Penataan merupakan suatu proses perencanaan dalam upaya meningkatkan keteraturan, ketertiban, dan keamanan. Penataan menjadi bagian dari suatu proses penyelenggaraan pemerintah dimana dalam proses penataan tersebut dapat menjamin terwujudnya tujuan pembangunan nasional. Penataan dapat dirumuskan sebagai hal, cara, hasil atau proses menata, (Lembong., Lapian., \& Kalangie, 2017). Menurut, Mouw \& Keradjaan, (2016) Administrasi Umum adalah kegiatan pencatatan data dan informasi mengenai kegiatan-kegiatan Pemerintahan Desa dimuat dalam Administrasi Umum.

\section{METODE}

Metode Pelaksanaan kegiatan pengabdian kepada masyarakat ini dilakukan dengan cara sebagai berikut: a) Penyampaian materi tentang Administrasi Pemerintahan Desa khususnya Buku Administrasi Umum berdasarkan Peraturan Menteri Dalam Negeri Nomor 47 Tahun 2016 Tentang Administrasi Pemerintahan Desa, dan b) Memfasilitasi pembuatan buku administrasi umum secara lengkap. Implementasi kegiatan dilakukan melalui tiga tahapan masing-masing; Tahap awal, kegiatan yang dilakukan adalah survey dan wawancara kepada aparatur kampung terkait kelengkapan administrasi umum, serta merancang kegiatan inti, Tahap inti, adalah tahap pelaksanaan kegiatan yaitu pelatihan kepada kepala kampung dan aparatur kampung mengenai 
Buku Administrasi Umum berdasarkan Peraturan Menteri Dalam Negeri Nomor 47 Tahun 2016 Tentang Administrasi Pemerintahan Desa, dan mendampingi pembuatan buku administrasi umum secara lengkap, dan Tahap akhir, kegiatan dalam tahap ini yaitu penyerahan Buku Pelatihan Administrasi Umum. Pada tahap ini, Tim Pengabdian menyerahkan Modul Buku Administrasi Umum kepada Kepala Kampung dan disaksikan oleh aparatnya.

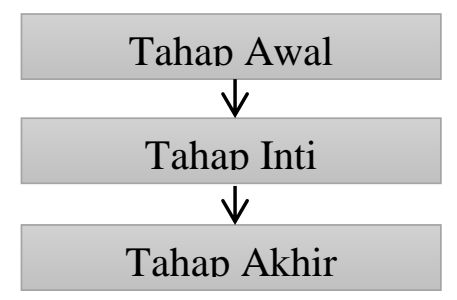

\section{Gambar 1: Tahapan Kegiatan}

\section{HASIL DAN PEMBAHASAN}

Kegiatan pengabdian ini dilaksanakan selama 2 (dua) hari. Berikut adalah rincian pelaksanaan kegiatan: Hari pertama, dilakukan survey awal, pada tahapan ini diadakan pertemuan dengan kepala kampung dan aparat kampung terkait dengan kelengkapan administrasi umum dan merancang pelaksanaan kegiatan inti. Kegiatan hari kedua, pemberian materi sekaligus pelatihan terkait Penataan Buku Administrasi Umum. Untuk materi yang disampaikan adalah mengenai administrasi umum yang terdiri dari: Buku Peraturan di Desa, Buku Keputusan Kepala Desa, Buku Inventaris dan Kekayaan Desa, Buku Aparat Pemerintah Desa, Buku Tanah Kas Desa, Buku Tanah di Desa, Buku Agenda, Buku Ekspedisi, dan Buku Lembaran Desa dan Buku Berita Desa.

Hasil yang dicapai adalah Aparat Kampung Yoboi Distrik Sentani Kabupaten Jayapura dapat memahami dan mengerti tentang administrasi umum sebagaimana yang tertuang dalam Peraturan Menteri Dalam Negeri Nomor 47 Tahun 2016 Tentang Administrasi Pemerintahan Desa. Selanjutnya, dilakukan penyerahan Buku Administrasi Umum kepada kepala kampung dan aparat kampung. Buku Administrasi Umum yang diserahkan ada 9 (Sembilan) buku berdasarkan Peraturan Menteri Dalam Negeri Nomor 47 Tahun 2016 Tentang Administrasi Pemerintahan Desa.

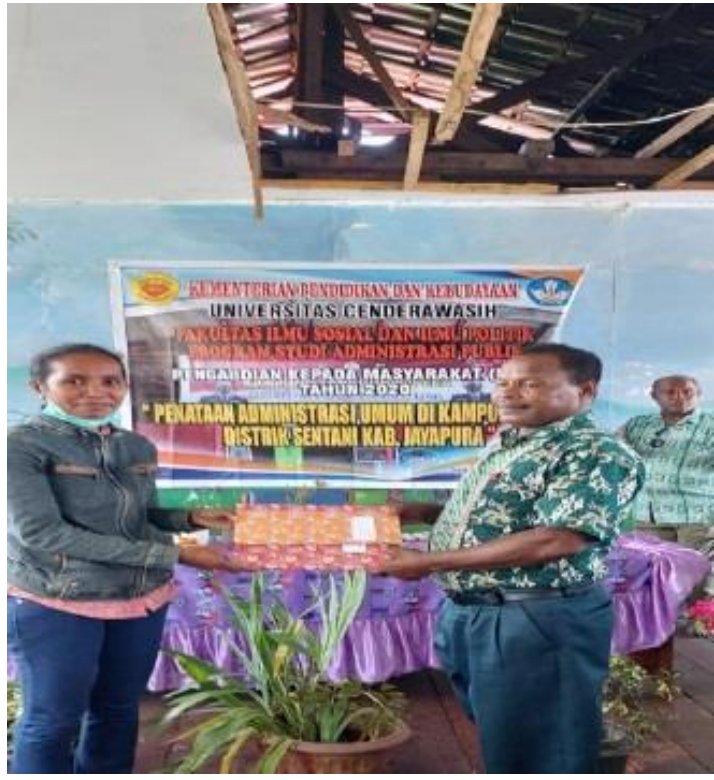

Gambar 1 : Penyerahan Buku Adminitrasi Umum Kepada Kepala Kampung

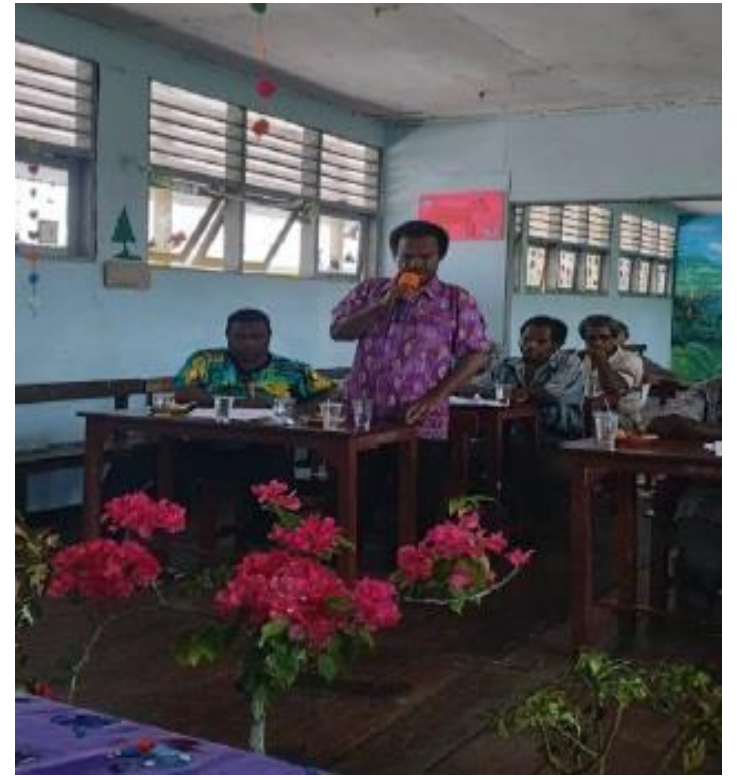

Gambar 2: Pemberian Umpan Balik (Feedback) dari Masyarakat 


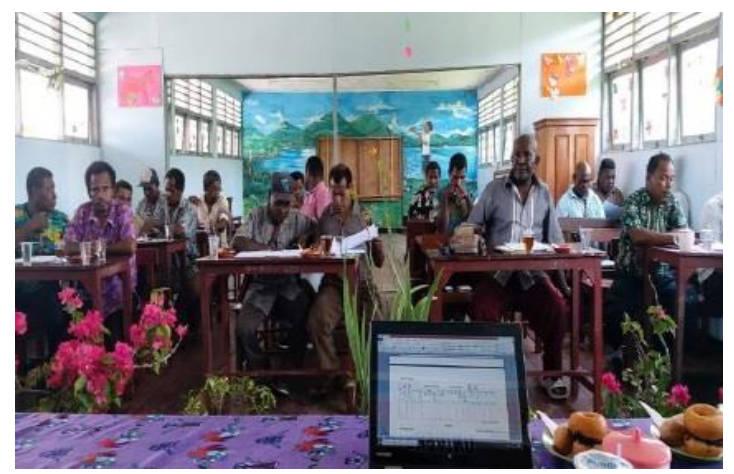

Gambar 3: Pelatihan Penataan Administrasi Umum Kampung Yobei

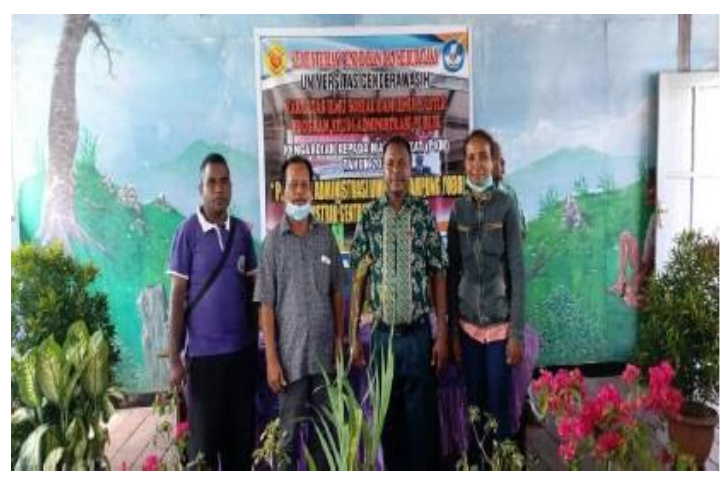

Gambar 4 : Foto Bersama Tim Pelaksana \& Kepala Kampung Yobei

Pelaksanaan kegiatan selama 2 (dua) hari berlangsung dengan baik. Dalam kegiatan penyampaian materi mengenai administrasi pemerintahan kampung, khususnya administrasi umum telah berlangsung dengan baik dan diikuti oleh seluruh aparat Kampung Yoboi. Dengan adanya penyampaian materi ini para aparat kampung baru mengetahui mengenai tata kelola administrasi pemerintahan kampung khususnya buku agenda surat masuk dan keluar serta buku adminnistrasi umum lainnya yang tertuang dalam Peraturan Menteri dalam Negeri Nomor 47 Tahun 2016 Tentang Administrasi Pemerintahan Desa. Aparat Kampung Yoboi mengakui pula bahwa selama ini mereka tidak membuat administrasi sesuai dengan aturan yang ada. Misalnya mengagendakan surat yang masuk ataupun keluar, mereka tidak pernah melakukan itu karena dengan alasan tidak mengetahuinya. Setelah dilakukan kegiatan pelatihan tata cara pengisian buku administrasi umum, hasilnya kepala kampung dan semua aparatur kampung yang hadir sebagai peserta pelatihan dapat mempraktekkannya dengan baik.

\section{SIMPULAN}

Kegiatan pengadian yang ditujukan untuk aparat kampung di Kampung Yoboi Distrik Sentani Kabupaten Jayapura telah didapatkan hasil sebagai berikut:

1. Aparatur Kampung Yoboi telah memahami penataan administrasi umum yang baik dan benar dan dapat mengisi ke dalam buku administrasi umum sesuai dengan pedoman yang terdapat dalam Peraturan Menteri Dalam Negeri Nomor 47 Tahun 2016 Tentang Administrasi Pemerintahan Desa.

2. Telah tersedianya Buku Pedoman Administrasi Umum di Kampung Yoboi.

\section{SARAN}

Sebagai rekomendasi yang diberikan tim penulis kepada aparatur pemerintahan Kampung Yoboi, Distrik Sentani, Kabupaten Jayapura agar sekiranya dapat secara terus menerus melakukan pendataan dengan tujuan untuk mengisi data-data informasi mengenai administrasi umum sesuai dengan buku administrasi umum yang telah dibuat.

\section{UCAPAN TERIMA KASIH}

Puji dan syukur kami panjatkan kehadirat Tuhan Yang Maha Esa karena atas rahmat dan anugerah-Nya sehingga kegiatan Pengabdian kepada Masyarakat (PkM) sebagai salah satu bagian dari Tridarma Perguruan Tinggi dapat terlaksana dengan baik, yang bertajuk "Penataan Administrasi Umum di Kampung Yoboi Distrik Sentani Kabupaten Jayapura". Oleh karena itu dalam kesempatan ini kami menyampaikan terima kasih kepada: Rektor Universitas Cenderawasih, Dekan Fakultas Ilmu Sosial dan Ilmu Politik, Kepala Lembaga Penelitian dan Pengabdian pada Masyarakat (LPPM) Universitas Cenderawasih, Ketua Program Studi Administrasi Publik FISIP- 
UNCEN. Ucapan terima kasih juga disampaikan kepada Kepala Kampung Yoboi beserta jajarannya, serta masyarakat Kampung Yoboi atas partisipasi dan dukungannya sehingga tahapan kegiatan yang telah terencana sebelumnya dapat berjalan dengan baik.

\section{DAFTAR PUSTAKA}

Arsjad, M. F. (2018). Peranan Aparat Desa dalam Pelaksanaan Administrasi Pemerintahan Desa di Desa Karyamukti Kecamatan Mootilango Kabupaten Gorontalo. Gorontalo Journal of Public Administration Studies, 1(1), 16-32.

Ilham., M. Z. Muttaqin., \& U. Idris. (2020). Pengembangan Bumkam Berbasis Potensi Lokal Di Kawasan Perbatasan Indonesia-Papua New Guinea. Communnity Development Journal, 1(2), 104-109.

Lembong, F., M.T. Lapian., \&, F. Kalainge. (2017). Penataan Administrasi Desa Dalam Menunjang Efektivitas Penyelenggaraan Pemerintahan Di Desa Tewasen Kecamatan Amurang Barat. Jurnal Eksekutif, 1(1), 1-15.

Mouw, E., \& H. Keradjaan. (2016). Pengelolaan Administrasi Pemerintahan Desa Studi Di Desa Wari Dan Wari Ino Kecamatan Tobelo. Uniera, 5(2), 19-26.

Pemerintah Republik Indonesia. (2015). Peraturan Menteri Dalam Negeri Nomor 81 Tahun 2015 Tentang Evaluasi Perkembangan Desa dan Kelurahan. Kementerian Dalam Negeri Republik Indonesia.

Pemerintah Republik Indonesia. (2016). Peraturan Menteri Dalam Negeri Nomor 47 Tahun 2016 Tentang Administrasi Pemerintahan Desa. Kementerian Dalam Negeri Republik Indonesia.

Prasodjo, T. (2017). Tata Kelola Administrasi dan Pengembangan Desa Inovatif Berbasis Riset. Jurnal Administrare: Jurnal Pemikiran Ilmiah Dan Pendidikan Administrasi Perkantoran, $4(1), 35-40$.

Yumame, J., Ilham., D. Renyaan., \& H. Sapioper. (2020). MEMBANGUN KAMPUNG BERBASIS DATA ( Pendampingan Penyusunan Monografi dan Profil Kampung Yobeh Distrik Sentani Kabupaten Jayapura ). Communnity Development Journal, 1(3), 246-253. 